\title{
Ein Zusatz zur Methode der kleinsten Quadrate.
}

\section{Von Professor Dr. Theodor Wittstein.}

$\$ 1$.

Bekanntlich bietet die Anwendung der Methode der kleinsten Quadrate nicht selten eine besondere Schwierigkeit, sobald die Function, von welcher eine Reihe beobachteter Werthe vorliegt, in Bezug auf die zu bestimmenden unbekannten Constanten nicht lineär ist, also entweder eine höhere algebraische oder eine transcendente. Gauss giebt für Fälle dieser Art die Vorschrift, man solle zuerst aus so viel Beobachtungen, wie Constanten zu bestimmen sind, angenäherte Werthe dieser Constanten berechnen und sodann, indem man die Function nach Maassgabe der noch fehlenden Correctionen in Reihen entwickelt und von diesen Reihen nur die ersten Potenzen dieser Correctionen beibehält, die so umgeformte Function der Methode der kleinsten Quadrate unterwerfen. Es ist augenscheinlich, dass man auf diese Weise eine Function erhält, welche in Beziehung auf die gesuchten Correctionen lineär ist, und somit wäre scheinbar alles in Ordnung. Aber Gauss selbst hat, unseres Wissens, seine Vorschrift niemals anders als auf lineäre Functionen selbst angewandt, wo die Anwendung derselben unmittelbar evident ist, und bezweckt damit im Grunde nur eine Erleichterung der Rechnung, welche dadurch eintritt, dass man mit kleineren Zahlen zu thun bekommt. Dagegen in Fällen, wo die Functionen nicht lineär sind, hat man in der Regel im Voraus gar keine Garantie dafür, dass in den gedachten Reihenentwickelungen die zweiten und höheren Potenzen der Correctionen wirklich weggelassen werden dürfen und nicht vielmehr diese Weglassung einen so bebedeutenden Einfluss ausübt, um die ganze Rechnung illusorisch zu machen. Uns ist mehr als ein Beispiel bekannt, wo man im vollen Vertrauen eine Rechnung in der vorbezeichneten Weise unternahm, jedoch für die gesuchten Correctionen so grosse Werthe fand, ja grösser als die zu corrigirenden Werthe selbst, dass das Resultat geradezu unmöglich war und die Rechnung aufgegeben werden musste.

\section{$\$ 2$.}

Es ist kaum abzusehen, ob diese Schwierigkeit jemals allgemein beseitigt werden kann. Wohl aber sind wir dahin gelangt, zu entdecken, dass dies für eine gewisse Klasse von Functionen allerdings möglich ist, nämlich wenn es gelingt, die gegebene Function durch die gewöhnlichen Operationen in eine andere umzuformen, welche lineär ist: wie 2. B.:

$$
\begin{array}{ll}
y=e^{a-b x} & \text { in } \log y=a \log e+b x \log e \\
y=\sin (a+b x) & \text { in } \quad \arcsin y=a+b x
\end{array}
$$

etc., wo die neuen Functionen lineär in Bezug auf die unbekannten Constanten $a$ und $b$ geworden sind. In Fällen dieser Art ist es immer möglich, die Werthe dieser Constanten vollkommen genau aus den neuen Functionen zu bestimmen, sobald man dabei nur einen Satz beachtet, den wir hier geben, wie folgt.

$$
\$ 3 \text {. }
$$

Lehrsatz. Wenn von einer Function $y$ eine Reihe von beobachteten Werthen $M$ etc., mit den Gewichten $p$ etc. versehen, gegeben ist, so kann man zur Bestimmung der in der Function enthaltenen unbekannten Constanten, anstatt die Summe der Fehlerquadrate dieser Function zu einem Minimum zu machen, vollkommen correct auch so verfahren, dass man die Summe der Fehlerquadrate einer beliebigen Function von $y$, welche $f(y)$ sei, zu einem Minimum macht, dabei jedoch jeder Beobachtung ein Gewicht $p_{1}$ beilegt, welches zu dem vorigen $p$ in der Beziehung steht

$$
\frac{p}{p_{1}}=k \cdot\left[\frac{d f(M)}{d M}\right]^{2}
$$

wo $k$ eine willkürliche und für alle Beobachtungen identische positive Constante bedeutet.

Der Beweis liegt einfach darin, dass wenn für dieselben Werthe der in der Function $y$ enthaltenen Constanten gleichzeitig sowohl

als auch

$$
\Sigma p(y-M)^{2}
$$

$$
\Sigma p_{1}[f(y)-f(M)]^{2}
$$

ein Minimum werden soll, dieses nur so möglich ist, dass alle Theile der einen Summe, Glied für Glied, den entsprechenden Theilen der anderen Summe entweder gleich oder von denselben um einen für alle Theile identischen positiven Factor verschieden sind. Nennt man $k$ diesen Factor, so muss man also haben

oder :

$$
\frac{p(y-M)^{2}}{p_{1}[f(y)-f(M)]^{2}}=k
$$

$$
\frac{p}{p_{1}}=k \cdot\left[\frac{f(y)-f(M)}{y-M}\right]^{2}
$$

woraus, da man für das Verhältniss der kleinen Differenzen $f(y)-f(M)$ und $y-M$ ohne Fehler das Verhältniss der Differentiale setzen darf, unmittelbar der oben gegebene Ausdruck folgt.

$$
\$ 4 \text {. }
$$

In den Anwendungen verfügen wir zur Vereinfachung der Rechnung über die willkürliche Constante $k$ so, dass wenn der Ausdruck

$$
\left[\frac{d f(M)}{d M}\right]^{2}
$$

einen constanten Factor liefert, d. h. welcher für alle Beobachtungen den nämlichen Werth hat, wir das Product aus $k$ mit diesem Factor $=I$ setzen. Ist ein solcher Factor nicht vorhanden, so nehmen wir unmittelbar $k=\mathbf{I}$.

So wenn in dem obigen Beispiel die Function

$$
y=e^{a+b x}, \quad \text { Gewicht }=p,
$$

umgeformt wird in 


$$
\log y=a \log e+b x \log e, \quad \text { Gewicht }=p_{1} .
$$

erhalten wir

$$
p_{1}=p M^{2}
$$

mit welchem Gewicht die Constanten dieser letzten Function, $a \log e$ und $b \log e$, berechnet werden missen.

Function

Ebenso .wenn in dem zweiten obigen Beispiel die

$$
y=\sin (a+b x), \text { Gewicht }=p,
$$

umgeformt wird in

$$
\operatorname{arc} \sin y=a+b x, \text { Gewicht }=p_{1} .
$$

erhalten wir

$$
\begin{gathered}
p_{1}=p\left(\mathrm{r}-M I^{2}\right) . \\
\& 5 .
\end{gathered}
$$

Wir setzen noch hinzu, dass nicht selten eine gegebene Function auf mehr als tine Art sich in eine lineäre Function umformen lässt, so dass man auswählen kann. Ein solcher Fall tritt z. B. ein, wenn man aus

ableitet
1) $y=a^{x}$,
Gewicht I

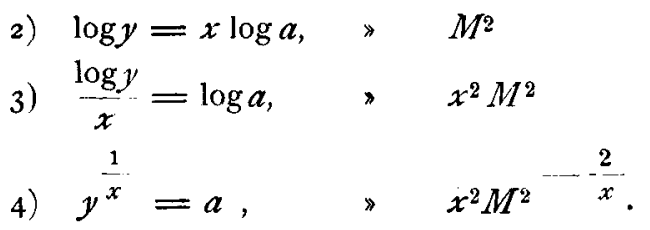

Wir haben ein numerisches Beispiel zur Bestimmung der unbekannten Constante $a$ nach allen diesen 4 Gleichungen, mit den hier beigesetzten Gewichten, durchgerechnet und die Arbeit in 2), 3) und 4) nahe gleich gross gefunden, während sie in r), wo der Weg der successiven Annäherung eingeschlagen werden musste, und wie wir hinzusetzen, mit Erfolg eingeschlagen werden konnte, ohne Vergleich grösser war. Das Endresultat der vier Rechnungen war genau dasselbe.

Hannover I 882 Juni.

\section{On the Period of the Variable R Hydrae.}

When considering this variable in the Uranometria Argentin a, pp. $300-302$, I showed that it was possible to represent, within reasonable limits, all existing observations of its maxima excepting Maraldi's, by means of a formula there given. This had been deduced upon the supposition of an error of one year in the date assigned for Maraldi's second maximum, which 1 assumed to be 1707 May 20 instead of I 708 May 20 ; and the accordance thus attained between the calculated epochs and the observed ones proved quite satisfactory. But at the same time I stated, that not having access to the original publication in the $\mathrm{M}$ émoires de Paris for 1709, no copy of which probably exists in all South America, it was impossible to know whether the supposition of such a misprint was tenable.

Visiting home during the autumn of 1880 , my attention was called by Mr. S. C. Chandler to the fact that the details given by Maraldi are totally incompatible with that supposition. This error was accordingly mentioned in the lists of Corrigenda in the Uranometry, published in No. 2377 of the Astr. Nachr., and in the second volume of the $*$ Results of the Cordoba Observatory «; and a new investigation was undertaken with such additional material as I had been able to collect.

This new investigation has been one of singular difficulty and labor, on account of a complication of embarrassing circumstances, and the need of numerous tentative processes for determining the number of periods elapsed in the intervals between the observed maxima. The observations of Hevelius and Montanari afford only approximate limits for the dates of the respective maxima; there is an uncertainty of two years as to Montanari's observation; and for nearly three quarters of a century, from Maraldi's observations to Pigott's, the star seems to have been utterly disregarded by astronomers. A single tolerably good determination between the years $I 7 \mathrm{I} I$ and $\mathrm{I} 7 \mathbf{8}_{4}$ would have made the problem comparatively easy, although the varying signs of the coefficients in the formulas when arranged according to powers of the time offer an additional difficulty.

Even now a certain amount of uncertainty remains, owing to the doubt regarding the year of Montanari's discovery. All the computations have therefore been made with equal care upon each of the two assumptions. Although I have myself but little doubt regarding the true year, the evidence is by no means thoroughly convincing and still less sufficiently unquestionable to make it needless to deduce the best results attainable upon each hypothesis. For this reason as well as others, it is important to consider minutely all the data at our disposal concerning the ancient observations.

r. Hevelius. Argelander cites the Machina Coelestis II $4 \mathrm{r} 3$, where are observations made 1662 Apr.I8, 19. The magnitude is not there given, although it is put down as 6 in Hevel's catalogue. Maraldi states (M ém. de Paris, 1706 p. r 17 ) that Hevel noted it as $5^{\mathrm{m}}$; but, as Argelander has pointed out, no evidence is to be found in favor of the assertion. Had the star been fainter than $6^{\mathrm{m}}$, it is improbable that Hevel would have seen it at all; and, had it been much brighter, his attention would probably have been specially attracted to it. We may therefore fairly assume, with Argelander, that it may have been 50 or 60 days from maximum at the time of these observations; and may regard all dates from February 22 to June $\mathbf{2} 2$ as about equally probable, in the absence of other information.

2. Montanari. I will quote Argelander's words, (Bonner Beobb. VII 34 I), correcting however a typographical error in his reference. 